\title{
CONSTRUCTING THE MEDICAL ÉLITE IN FRANCE: THE CREATION OF THE ROYAL ACADEMY OF MEDICINE 1814-20
}

by

\section{GEORGE WEISZ*}

It is now widely recognized that medical science was dramatically transformed from the mid-eighteenth to the early-twentieth centuries, while, at the same time, the organized medical profession came increasingly to monopolize health care in the western world. Less well known is the parallel shift, during this same period, of institutional power within medicine. At the beginning of the eighteenth century, it was vested in a multitude of regional corporate ellites; by the end of the nineteenth century, it was wielded by national élites whose power sprang from the control of key institutions, notably medical schools, hospitals, licensing bodies, and public health agencies. In England, corporate élites adapted to new conditions and gradually transformed themselves into an élite of the modern type. ${ }^{1}$ In France, however, this mutation involved a far greater degree of discontinuity between old and new élites. Political intervention, moreover, consistently played a determining role, In many ways, it was the state which created the medical élite and the modern profession of medicine in France.

This transformation has not been systematically investigated by historians of medicine more fascinated by the profession's collective appropriation of power, prestige, and wealth. For the historical actors themselves, however, the question of institutional authority had been a consuming preoccupation, with profound implications for the development of medicine. This has been as true of nations where institutional power is relatively decentralized, as it is in France where centralization in nearly all domains has tended to breed chronic forms of rebellion against institutional authorities.

The transformation of medical power in France was a gradual process occurring over nearly two centuries. The final four decades of the ancien régime were instrumental in setting the pattern for extensive state intervention in health care. Even more fundamentally, the years from 1794 to 1803 saw the establishment of a state

*George Weisz, PhD, Department of Humanities and Social Studies in Medicine, McGill University, 3655 Drummond Street, Montreal, Canada H4G 1 Y6.

Research for this article was made possible by grants from the Hannah Institute and the Social Sciences and Humanities Research Council for Canada. I owe special thanks to my research assistant Donna Evleth for her invaluable aid.

${ }^{1}$ This at least is the argument advanced in Jeanne Peterson, The medical profession in mid-Victorian London, Berkeley, University of California Press, 1978. 
system of medical education and licensing. These seminal periods will be discussed only briefly in the following paper, which concentrates on the years 1814-20, during which the state's role in health care was consolidated and extended in subtle but important ways by two decisions. First, the governments of the Bourbon Restoration faced a unique opportunity to transform radically the system of institutional power constructed by the Revolution and especially the Empire; this opportunity was not exploited, despite a massive public campaign directed against existing institutions. Second, the government chose to establish, as the primary instrument of its public health policy, the Royal Academy of Medicine, which brought together hitherto separated medical specialities as well as the diverse institutional élites which had developed since the Revolution. It came to serve as the major advisory body to the government for all health-related matters; it evaluated medical publications, awarded prizes, collected and examined epidemiological information, administered smallpox vaccinations, and supervised secret remedies and mineral waters. The Academy, it is true, failed in many ways to fulfil initial expectations. Nevertheless, it enjoyed a remarkable degree of responsibility and prestige. ${ }^{2}$

Both the maintenance of the system inherited from the Empire and the creation of the Academy reflected the growing determination of successive governments since the eighteenth century to expand the role of the state in the fields of public health and medical care. At the same time, both reflected the intense competition among medical groups, both old and new, for the right to represent this growing state authority. In reconstructing the events leading to the establishment of the Academy, this essay seeks to shed light on one of the major influences on the evolution of medicine in France; the interaction between administrative centralization and corporate self-interest.

In what follows, I shall first analyse the system of professional and institutional power that emerged from the dislocation of revolution. I shall go on to describe the unsuccessful campaign from 1814 to 1817 which attempted to break the power of the new medical élite by affecting a separation between medicine and surgery. Finally, I shall examine the process which led to the establishment of the Royal Academy of Medicine in 1820 . This process, I shall argue, was in large measure a continuation of the struggle for medical authority begun in 1814 and increasingly intertwined with the wider political struggles of the Restoration.

\section{THE MEDICAL DOMAIN}

As in so many other spheres, the Revolution of 1789 brought a new degree of centralization to the medical domain in France. Despite a general movement toward more centralized forms of authority, medical institutions of the eighteenth century had remained highly fragmented. Rather than referring to a single medical domain, one must speak of several, each with its own practices, cognitive foundations, and forms of authority. ${ }^{3}$

\footnotetext{
${ }^{2}$ Space limits preclude a discussion of the Academy's role and history in the nineteenth century. Although there exists no good historical study of the institution, one can read with profit Paul Ganière, $L$ 'Académie de Médecine: ses origines et son histoire, Paris, 1964; and Centenaire de l'Académie de Médecine, Paris, 1921.

${ }^{3}$ The word "domain" in this context refers to a configuration of social activities and institutions which are generally recognized by historical actors themselves to possess some degree of commonality. They are usually composed of more or less distinct subsectors whose relationships one to another are fluid as are the
} 


\section{Constructing the medical élite in France}

In order fully to comprehend this fragmentation, it is useful to conceptualize authority over collective medical activity into the following categories: (1) the power to train future medical practitioners; (2) the power to determine who can practise through licensing of one sort or another; (3) the power to advise governmental authorities systematically in all matters of public health, ranging from measures to counter epidemics or regulate secret remedies to legislation governing medical practice; (4) responsibility for securing the progress of medical science, delineating legitimate cognitive activity, and validating discoveries; (5) disciplinary authority over the professional (and sometimes private) behaviour of practitioners; (6) control of hospitals, which were rapidly becoming indispensable for training and the accumulation of knowledge.

Such forms of authority during the ancien régime were extremely dispersed, due partly to traditional guild divisions and partly to the government's penchant for creating new institutions as new needs arose or as the performance of existing institutions was judged inadequate. ${ }^{4}$ Medical practitioners, first of all, were divided into three types of professional guilds, of medicine, surgery, and pharmacy, each with its separate institutional structures. In addition to division along professional lines, medical jurisdiction was fragmented along regional lines, with the authority of each institution confined to a limited geographical area. Physicians were more or less educated in eighteen faculties of medicine spread throughout the kingdom. Apprenticeship of one sort or another remained the primary form of training for most surgeons and pharmacists; but surgeons, at least, were increasingly being educated in programmes of study organized in the guild-like colleges of surgery or in the course of extended hospital service. Furthermore, lectures and instruction useful to future practitioners were available privately or in a wide variety of institutions ranging from the Collège du Roi and Jardin du Roi to local corporate institutions (colleges).

Among surgeons, formal education was largely controlled by the colleges; consequently, teaching authority was closely bound up with licensing powers. Even here, the existence of relatively autonomous hospital training provoked tensions. In medicine, the split between education and licensing was more serious. Only in Paris did

\footnotetext{
definitions of which groups and institutions do or do not belong to the domain. "Domain" as I use it bears some resemblance to the term champs ("field") developed by Pierre Bourdieu throughout his writings. If I prefer the word "domain", it is partly to avoid unnecessary sociological jargon; but it is also an effort to distance myself from some of the conceptual implications of Bourdieu's terminology, i.e. for Bourdieu, a "field" is almost exclusively a battleground for power and prestige among individuals and groups wielding various forms of social capital. In contrast, "domain", as I use it, is a far more open term whose precise characteristics and structures are subject to empirical enquiry.

${ }^{4}$ Among recent works shedding light on the structure of French medicine during the eighteenth century see especially Toby Gelfand, Professionalizing modern medicine: Paris surgeons and medical science and institutions in the eighteenth century, Westport, Conn., Greenwood Press, 1980; Caroline Hannaway, 'Medicine, public welfare and the state in eighteenth-century France: the Société Royale de Médecine of Paris (1776-93)', PhD thesis, Johns Hopkins University, 1974. Also see chs. 3 and 4 of Charles C. Gillispie, Science and polity in France at the end of the Old Regime, Princeton, NJ, Princeton University Press, 1980; Matthew Ramsey, 'Traditional medicine and medical enlightenment: the regulation of secret remedies in the Ancien Régime', and Pascale Cosma-Muller, 'Entre science et commerce: les eaux minérals en France à la fin de l'Ancien Régime', both in Jean-Pierre Goubert (editor), La médicalisation de la société française 1770-1830, Waterloo, Ont., Historical Reflections Press, 1982. Among older works on the subject see especially Paul Delaunay, La vie médicale aux XVIe, XVIIe et XVIIIe siècles, Paris, 1935; and idem, Le monde médical parisien au dix-huitième siècle Paris, 1905.
} 


\section{G. Weisz}

the university diplomas also carry the right to practise. Elsewhere, licensing was in the hands of colleges, a situation giving rise to conflicts between these and medical schools. The king, moreover, could authorize any practitioner, whatever his credentials, to practise in Paris by naming him to the court medical staff (the Faculte du Roi), which itself constituted a major source of institutional power in medicine.

Disciplinary authority over practitioners was wielded primarily by the colleges. Authority over the development of medical science had largely been displaced from the Paris Faculty of Medicine to state institutions of science like the Academy of Sciences (which contained large numbers of doctors) and later, the Royal Society of Medicine. Authority over public health was in the hands of local officials and, increasingly, the central government. Bewildered by the complexity of most issues, these were becoming more and more dependent on medical experts in such bodies as the Royal Society of Medicine and Academy of Sciences. Hospitals were controlled by religious orders and local political authorities; the role of medical practitioners, particularly surgeons, was becoming significant but their authority in the hospital remained limited.

The eighteenth century saw increasing, if still tentative, governmental efforts to reorganize health under state control. The unification of surgery after 1730 in the hands of the king's first surgeon, reflected traditional patronage concerns, notably the need to reward loyal servants of the state with corporative privileges; but it also came to express a more activist state policy aimed at imposing greater uniformity. The centralization of many traditional research and public health tasks in the hands of the Royal Society of Medicine represented an even more significant step in this direction. ${ }^{5}$ It was patterned after the several royal academies established since the seventeenth century in order to organize scientific and cultural life under royal patronage and control. 6

Behind the effort to expand the state's role in medical care was the vision of a reorganized medical domain at once unified and oriented toward public health. Such concern with the health of populations was characteristic of most European nations and was justified by a set of policies that characterized monarchical despotism and that have come to be known as cameralism or mercantilism; these sought to increase the productive capacities of the nation through direct state intervention. ${ }^{7}$ Prussia and Austria, in fact, were considerably in advance of France in laying the groundwork for a comprehensive reorganization of public health. In France, the scope of public health seems to have been defined primarily by the existence of traditional areas of state intervention: measures to deal with epidemics, health-care programmes for the destitute, and the licensing of secret remedies and mineral waters which served largely as a means of rewarding royal appointees with revenue-producing prerogatives.

\footnotetext{
${ }^{5}$ On these matters see Hannaway, op. cit., note 4 above; Gelfand, op. cit., note 4 above; and Othmar Keel, 'Cabanis et la généalogie de la médecine clinique', PhD thesis, McGill University, 1977.

${ }^{6}$ On the early academies of the ancien régime see Roger Hahn, The anatomy of a scientific institution: the Paris Academy of Sciences 1666-1803, Berkeley, University of California Press, 1971, pp. 1-34. On provincial academies and their relationships to those in Paris see Daniel Roche, Le siècle des lumières en province: académies et académiciens provinciaux 1680-1789, Paris, École des Hautes Etudes en Sciences Sociales, 1978.

${ }^{7}$ Marc Raeff, 'The well-ordered police state and the development of modernity in seventeenth- and eighteenth-century Europe', Amer. hist. Rev. 1975, 80: 1221-1243. On cameralism in medicine see George Rosen, 'Cameralism and the concept of medical police', Bull. Hist. Med. 1953, 27: 21-42.
} 
Toward the end of the eighteenth century, spokesmen for medicine and the state administration began popularizing reform programmes to rationalize these activities and, not incidently, affirm the powers of the state at the expense of traditional corporate groups.

A key aspect of the public health programme was the creation of institutions to produce and sanction new medical knowledge. This was a major function of both the Royal Society of Medicine and Royal Academy of Surgery. There was no sharp distinction between clinical research and public health in the minds of medical reformers of the eighteenth and early nineteenth centuries. Their association would apply to medicine the pattern established in the Academy of Sciences which combined the production and sanctioning of knowledge with the provision of technological expertise to the state. This identity was also an inevitable result of the inadequacies of existing medical knowledge. Improving the people's health required major advances in medical science. It also required a body of experts to choose, from among the contradictory welter of medical systems and opinions, principles of administrative action. At the same time, the production of new knowledge was dependent on reorganizing the medical profession along new public health lines into a huge network of information collection, the results of which were to be processed, analysed and eventually applied by a Parisian élite.

In the course of the French Revolution, this institutional system was largely swept away. The new one established piecemeal during the following decade owed much (including some of its key personnel) to the ancien régime and, in many ways, carried to their logical conclusion eighteenth-century tendencies. But it was notably streamlined, with power becoming highly concentrated in the hands of representatives of the state. Only three schools (called "faculties" after 1803) of medicine could offer complete training to all future doctors of medicine and surgery. The diplomas which they granted also served as licences to practise throughout the nation. Disciplinary authority over the profession, previously invested in corporate bodies, was never fully restored. Authority over both public health and the advancement of medical science was included among the responsibilities of the medical faculties-particularly the Faculty of Paris-from their very inception. Because these tasks were so timeconsuming, the government allowed the Paris Faculty of Medicine to establish an academic society around the Faculty by adding thirty-two associate and adjunct members. ${ }^{8}$

Prerogatives this vast were in many respects unenforceable. A variety of institutions sprang up to fill the many gaps in the faculties' activity. The latter, for instance, could not possibly train enough highly-qualified doctors to serve the country's needs. Since local medical élites insisted on offering courses of medical training, informal schools centring on the local hospitals developed in many cities. These were integrated into the medical education system from 1806 to 1809 , becoming écoles secondaires de médecine. They were permitted to teach the first two years of the four-year programme for the

\footnotetext{
${ }^{8}$ On the establishment of the Society of the Faculty see the dossier in Archives Nationales AJ16 6705. Also see Pascale Zweibel-Muller, 'La Société de l'École de Médecine et la santé publique en France de 1801-21', thèse 3e cycle, École des Hautes Études en Sciences Sociales, No. 1663 [n.d.]. Hereinafter, all references beginning with AJ16, F17 or F15 refer to cartons at the Archives Nationales in Paris.
} 


\section{G. Weisz}

doctorate, but their primary role was the training of low-level officiers de santé to work in the countryside. Departmental juries made up of Faculty professors and representatives of the local medical profession examined and licensed officiers and other low-level practitioners such as midwives. They also played a minor and not always satisfactory role in regulating local practice by inspecting pharmacies and combating illegal practice.

In the three faculty cities, a variety of private teaching institutions sprang up to remedy the manifest inadequacies of faculty teaching. Private instruction in Paris was especially rich and diversified. After 1811, the Parisian hospitals began playing a particularly significant role in medical education by offering courses. Hospitals everywhere, moreover, developed internships and externships (akin to clerkships in British hospitals) which provided the brightest medical students (chosen by public competitions) with invaluable practical training and experience. Through this institution, education for the future medical élite became centred in the hospital rather than in faculty courses. Military physicians and surgeons were also trained in an autonomous system of military hospitals, despite faculty efforts to share in this role. ${ }^{9}$ Medical research of one sort or another took place in a variety of teaching and therapeutic institutions. But only the Paris Faculty of Medicine and the Academy of Sciences could claim any formal authority to direct and validate the search for new medical knowledge. Similarly, from the purely juridical standpoint, the faculty monopoly over education and licensing was more or less complete, even if unenforceable.

In public health and sanitation, administrative responsibilities were badly defined because of conflicting ministerial jurisdictions and the multiplicity of functional and regional bodies involved. ${ }^{10}$ But the state at least attempted to direct activities in a wide variety of spheres and was in constant need of technical expertise. The Ministry of the Interior, which played a particularly important coordinating role, was largely dependent on the advice of the Paris Faculty of Medicine. The faculty, in fact, was regularly bombarded with requests for information and advice about epidemics, epizootics, secret remedies, and mineral waters; other requests came from judges, prefects, and local authorities. ${ }^{11}$ Professors were sent on missions to study epidemics in the provinces and abroad. In 1805-6, the Ministry of the Interior established a network of epidemic doctors distributed throughout the country. Incumbents were expected to direct medical work in the event of outbreaks and to send reports to the ministry in the aftermath. Significantly, these reports were supposed to be studied by the Paris Faculty. ${ }^{12}$ The Faculty was frequently called upon to recommend physicians to the

\footnotetext{
${ }^{9}$ See, for instance, the proposal to reform the organization of military hospital instruction submitted to the Conseil de l'Université, 31 August 1813, in Ministère de l'Instruction Publique, Enquêtes et documents relatifs à l'enseignement supérieur, 124 vols., 1883-1929, vol. 37, pp. 23-31; also see the undated report in F17 2107. On the relationship of the faculty to military medicine during the nineteenth century, see [anon.], 'Le service de santé militaire et l'enseignement supérieur', Revue internationale de l'Enseignement, 1899, 37 : 481-502.

10 Jacques Léonard, Les médecins de l'Ouest au XIXe siècle, Lille, Atelier Reproduction de Thèses, 1976, p. 444.

${ }^{11}$ For an idea of its manifold tasks see the procès verbaux of the Faculty of Medicine from 1795 to 1807 in AJ16 6226 and 6227 . Also see F17 6697 and F15 2738; Léonard, op. cit., note 10 above, pp. 325-328.

12 Ibid., p. 447.
} 


\section{Constructing the medical élite in France}

administrators of hospitals and dispensaries seeking to make medical appointments. ${ }^{13}$

All this work was done without remuneration, and the strain on faculty resources was enormous. The creation in 1800 of the Society of the Faculty of Paris did not improve matters significantly. Consequently, by the end of the Empire, there arose, among both administrators and professors, the idea of transforming the Society of the Faculty into a larger and better-endowed society along the lines of the old Royal Society of Medicine and Royal Academy of Surgery.

The task of advancing medical knowledge was in some respects even more of a problem. Certainly, the Faculty of Paris counted some of the best-known medical scientists in the world among its staff. Its professors were members of such prolific societies as the Société Médicale d'Emulation. However, neither the faculty nor its society appeared particularly successful as institutions in either stimulating and directing medical research or resolving the many doctrinal disputes characteristic of this period. The results of the society's collective scientific activity were not impressive. It never succeeded in fulfilling a central part of its mandate, publishing the papers of the Royal Society of Medicine and Royal Academy of Surgery. Its monthly bulletin was exceedingly thin and was distributed as a supplement to the Journal de Médecine, Chirurgie et Pharmacie. Certainly, this aspect of its activity was in a sense a casualty of its public health responsibilities, which left the society little time for anything else. Notwithstanding, to contemporaries, the activities of the society did not seem very significant in view of the enormous power and resources at the faculty's disposal. ${ }^{14}$

This predominance, it must be emphasized, was not acceptable to many segments of the medical profession. In 1797-98, for instance, when the three schools of medicine were not yet granting state diplomas, the school of Paris was violently criticized in legislative debates concerning the future reform of medicine. The Legislature's Commission of Public Instruction proposed to introduce a far more decentralized system, making the advancement of science uniquely a responsibility of the French Institute, and cutting back significantly on the Paris Faculty's resources, staff, and facilities. $^{15}$

In 1801, representatives of the defunct Royal Academy of Surgery announced to the new First Consul that they were resuming their activities, and requested official

\footnotetext{
${ }^{13}$ Appointments to the private Philanthropic Society, for instance, were made on the basis of recommendations by the Paris Faculty. See Dora B. Weiner, 'The role of the doctor in welfare work: the Philanthropic Society of Paris 1780-1815', in Goubert (editor), op. cit., note 4 above, pp. 279-304. For a case in which the Faculty organized a concours at the Charite hospital to elect a chief physician for the hospital of Meaux see Bulletin de l'École de Médecine de Paris, 1807, no. 1, p. 3.

${ }^{14}$ According to the Journal général de Médecine, 2e série, 1821, 15: 133-136, "this meagre bulletin could not have born comparison with the weakest scientific journals of the capital." This view is largely shared by Zweibel-Muller, op. cit., note 8 above. However, M.-J. Imbault-Huart, L'Ecole Pratique de Dissection de Paris de 1750 à 1822, ou l'influence du concept de médecine pratique et de médecine d'observation dans l'enseignement médico-chirurgical au XVIIIe siècle et au début du XIXe siècle, Lille, 1975, p. 246, argues that this bulletin was more significant than is generally supposed. That faculty professors were sensitive to such charges is illustrated by a speech in AJ16 6705 made at the turn of the century by B. Peyrilhe. The subject was "Can the functions of the medical professor be usefully reconciled with the development of literary or academic knowledge?".

${ }^{15}$ The relevant documents are reprinted in Enquêtes et documents, op. cit., note 9 above, vol. 28. For the Faculty's response see Observations adressés par l'École de Santé de Paris au Conseil des Cinq Cents en réponse aux imputations contenues dans plusieurs opinions émises à la tribune, 17 germinal An VI, Paris, 1798.
} 


\section{G. Weisz}

governmental "protection and succour" as well as a return to the corporate divisions of the ancien régime. ${ }^{16}$ It was not just the reactionary remnants of ancien régime who called for a return to the old order. In that same year, the very progressive Society of Medicine of Paris, to be discussed below, responded to Napoleon's invitation to submit a proposal on methods of combating charlatanism by insisting on the necessity of re-establishing medical corporations "freed ... of their ancient abuses and of everything that could offend the constitution ... but freely exercizing this active surveillance." These corporations or colleges had to be numerous enough to ensure that current medical anarchy should not be replaced by "a no less dangerous aristocracy; that henceforth, no form of despotism weighs down on citizens who cultivate the art of healing, not even that of talent which is not the least dangerous."17

The government of the Empire ignored these arguments. Accepting the views of such political figures as Chaptal, Fourcroy, and Cabanis, it opted for a unified profession and administrative centralization. It seems to have been motivated in equal measure by the prevailing beliefs that (1) a single medical science now underlay all forms of medical practice; (2) the faculty really did represent the élite of medical science and practice; (3) the government's need for expert information could be met with greater ease by a centralized institution like the Society of the Faculty than by a number of distinct corporations. ${ }^{18}$

Consequently, the authority of the School of Paris grew enormously during the first years of the Empire. The law regulating medical practice in 1803 accorded the faculty a monopoly over the granting of the doctorate. Certainly, it was widely recognized that both medical education and the organization of the profession needed drastic overhauling. But the government generally appointed Parisian professors to the commissions discussing reforms. ${ }^{19}$ It is thus not surprising that opponents of the faculty abandoned the strategy of direct assault. Until 1814, they waited for better days or sought to establish themselves in areas where the faculties' hold was weak. Most important for our purposes, a number of medical societies set themselves up as unofficial competitors of the Society of the Faculty, seeking through superior performance to win official recognition from the government. They followed a classic strategy of the ancien régime, one pursued by Lassone and Vicq d'Azyr in setting up the Royal Society of Medicine. This strategy, however, reflected the realities of the eighteenth century rather than those of the nineteenth.

Medical societies began to proliferate from 1796. Above all, they represented the attempt at reorganization by medical groups that had lost their traditional corporate

\footnotetext{
${ }^{16}$ Adresse présenté au Premier Consul par les commissaires de l'Académie de Chirurgie, An IX in F17 3679. Doctors were not alone in seeking a return to corporate structures. For the case of barristers see Michael Fitzsimmons, 'Dissolution and disillusionment: the Parisian Order of Barristers 1789-1815', PhD thesis, University of North Carolina, 1981.

17 'Adresse de la Société de Médecine de Paris au Premier Consul de la République', Journal général de Médecine, 1801, 10: 199-200.

18 The thinking of government spokesmen is illuminated by two administrative reports prepared in 1801 in response to the surgeons' request for a return to corporations. They are in F17 3679.

19 In 1811 , for instance, the minister named a commission of ten members to regularize the training of officiers de santé. The commission included five professors at the Faculty of Paris, two professors of the Museum of Natural History (Cuvier and de Jussieu) and two inspectors-general of the University (Dupuytren and Royer-Collard, one a professor and the other a future professor at the Faculty of Medicine).
} 
structures during the Revolution. Some were concerned predominantly with professional affairs. Others, notably the Société Médicale d'Emulation, were primarily interested in advancing the frontiers of medical knowledge. Two in particular brought together many of those seeking to challenge the powers of the Paris Faculty of Medicine: the Medical Society of Paris and the Academic Society of Paris. The Medical Society of Paris was the first medical society established after the Revolution (1796). Many of its founding members had formerly been members of either the Royal Society of Medicine or the Royal Academy of Surgery and viewed the new society as the legitimate successor to these illustrious institutions. It maintained regular contacts with the civil authorities, especially those of the Paris region, on all matters relating to public health, and occasionally sent commissions to study epidemics. It offered free consultations to the poor and became closely linked with the semi-official Commission of Vaccination founded a few years later. It sought to advance medical science by offering prizes for written works, and published the famous Journal général de Médecine française et étrangère. By 1801, it had 444 members and 100 correspondents. ${ }^{20}$

The society played a significant public health role in the Paris region by acting as technical adviser to the prefecture; but it was not taken seriously by the central government. It was so completely ignored, in fact, that Napoleon's invitation in 1801 to present him with ideas on the repression of charlatanism provoked scarcelyconcealed euphoria. After years of being completely ignored by the government, it stated in its response that the First Consul had finally "consecrated its legal existence". ${ }^{21}$ But its suggestions were not implemented, and the society appears to have concentrated exclusively on its scientific and public health activities until the fall of the Empire.

The second society was far less significant as a rival in the scientific or public health fields but was far more of a nuisance to the government. The Academy of Medicine of Paris was founded in September 1804 by a group of regent-doctors of the eighteenthcentury faculty of medicine, including the famous Dr Guillotin. ${ }^{22}$ Its stated goal was to bring doctors together in order to raise the status of medical practice. The choice of the name "Academy" reflected its pretension to semi-official status. At its second meeting, in fact, it passed a motion requesting the Emperor to grant it the title Imperial Academy of Medicine. ${ }^{23}$ Its request was ignored and the government soon forced it to change its name to the slightly less official-sounding Academic Society. Its membership was dominated by members of the defunct faculty; its director, Guillotin, had been a professor, while the first president, Bourru, had been dean. It admitted the graduates of the post-revolutionary schools of medicine but deprived them of influence by setting up an elaborate system of hierarchical distinctions.

\footnotetext{
${ }^{20}$ On the history of this society see Société de Médecine de Paris 1796-1896: centenaire, Paris, 1896. Also see the report by Nacquart and Sedillot to the prefect of the Seine reprinted in Journal général de Médecine, Chirurgie et Pharmacie, 2e série, 1818, 3: 145-156.

21 'Adresse de la Société de Médecine', op. cit., note 17 above, p. 199.

22 A good general history of the Academy is R. Pichevin, 'La première Académie de Médecine de Paris', Bull. Soc. française Hist. Méd., 1913, 12: 196-231.

${ }^{23}$ Minutes of the Academy, 26 vendémiaire An XIII, Académie de Médecine (A.M.), MS 42.
} 


\section{G. Weisz}

Though it performed some useful activities, such as offering free consultations to the poor, its chief goal seems to have been the restoration of the corporate trappings and privileges of the old faculty. At an early meeting, it was decided that disciplinary surveillance over members would be maintained. ${ }^{24}$ In this way, it was seeking to recreate corporate powers by extra-legal means and was insinuating itself into the realm of professional discipline where the vacuum created by the Revolution had never been filled. In a variety of public statements, representatives of the society admitted that their goal was to raise from the ashes the old Faculty of Medicine. ${ }^{25}$ This ambition, however, was undermined by internal dissensions. From 1809 to 1811 , the Academic Society split apart into two separate societies. ${ }^{26}$ A group led by Antoine Portal of the Collège de France seceded from the parent Academic Society to create the Cercle Médical, a name he chose after being denied permission by the government to use the title Academy of Medicine and to exercise disciplinary power over members. ${ }^{27}$

The combined efforts of the Academic Society and the Cercle Médical to undermine the Paris Faculty of Medicine, while in some respects risible, reveal the impotence of opponents of the faculty during the Empire. Despite its widely-recognized inability to fulfil all its multiple roles, the faculty was an integral part of the general system of centralized power developed by the regime. ${ }^{28}$ It was thus futile to attack it directly. The alternative was to win symbolic titles and, on a small scale, corporate disciplinary powers; or, like the Society of Medicine of Paris, to carve out an autonomous niche by assuming public health and scientific functions which the Faculty of Medicine was performing inadequately or not at all. The fall of the Empire, however, changed conditions entirely.

\section{THE CAMPAIGN TO SEPARATE SURGERY FROM MEDICINE}

Soon after setting foot on French soil on 19 April 1814, Louis XVIII received a statement of welcome from the Faculty of Medicine assuring him of its loyalty. ${ }^{29}$ Despite the well-known Bonapartist sentiments of certain professors, the new government was not disposed to take action against the Faculty. The new Minister of the Interior, the Abbé de Montesquieu, in fact, expressed interest in expanding the Society of the Faculty into a full-fledged Academy. ${ }^{30}$ The idea was not a new one. ${ }^{31}$ As

\footnotetext{
${ }^{24}$ Minutes, 7th session, February 1805, A.M., MS 42, p. 9.

${ }^{25}$ For instance, the speech by Pagès cited in Pichevin, op. cit., note 22 above, p. 213.

${ }^{26}$ The split is described in ibid., pp. 219-25, and massively documented in F17 1147, 2738, 2455, 3679.

${ }^{27}$ On these matters see Portal's Note sur l'Institut de Médecine de Paris in F17 2738, and an administrative report to the minister of the interior [n.d.] in F17 2738.

${ }^{28}$ The extent of this integration can be gauged by the fact that Napoleon ennobled eight professors of medicine at the Paris Faculty and two at the Faculty of Montpellier. The list of 51 doctors ennobled is in P. Huard, Sciences, médecine, pharmacie 1789-1815, Paris, Dacosta, 1970, pp. 298-303.

${ }^{29}$ The most complete study of medicine during the Restoration remains Paul Delaunay, Les médecins, la Restauration et la révolution de 1830, Paris, 1931-32. A useful recent study is Jacques Léonard, 'La Restauration et la profession médicale', in Goubert (editor), op. cit., note 4 above, pp. 69-84. Among the many studies of political life during the Restoration see especially Guillaume Bertier de Sauvigny, The Bourbon Restoration, Philadelphia, 1966. For a brief but illuminating interpretation see Alan B. Spitzer, 'The ambiguous heritage of the French Restoration: the distant consequences of the Revolution and the daily realities of the Empire', in Jaroslaw Pelenski (editor), The American and European revolutions, 1776-1848: sociopolitical and ideological aspects, Iowa City, 1980, pp. 208-226.

${ }^{30}$ See his letter to the Faculty in F17 3680. It is reprinted in Réflexions sur l'établissement d'une Société Royale de Médecine et de Chirurgie, Paris, 1815, pp. 1-2.
} 


\section{Constructing the medical élite in France}

has so often been the case with institutional reform in France, the change in regime seemed like a particularly appropriate opportunity to reform existing institutions. Such a measure may have appealed to France's new rulers because it emphasized and appeared to renew the monarchy's traditional concerns with the health of the nation, symbolized by the posthumously prestigious Royal Society of Medicine and Royal Academy of Surgery.

At about the same time, a group of Parisian surgeons presented the new king with a petition calling for the re-establishment of the College of Surgery and the Royal Academy of Surgery as well as the return of their building and facilities now in the hands of the Faculty of Medicine. In their view, (1) the institutions of the ancien régime had been far more successful in producing high-quality practitioners and in advancing knowledge than the current faculty; (2) their proposal represented the restoration of legitimate institutions destroyed by revolutionary usurpers. ${ }^{32}$ But their arguments do not appear to have carried much weight at the Ministry, more influenced by a report prepared by the Faculty. ${ }^{33}$ This report defended the unity of medicine and surgery and proposed the establishment of a single Royal Society of Medicine and Surgery responding to governmental enquiries about epidemics, epizootics, legal medicine, secret remedies, and mineral waters.

In justifying its proposal, faculty representatives also emphasized the continuity of their institution with those of the ancien régime. But above all, they insisted that the government would find a single institution to which it could address itself far more efficient and convenient: "relations will be much more prompt, much more sure than if it had been necessary to consult two groups." The new institution would put in the hands of the government "a unique, prompt and powerful means of aiding its people afflicted by contagious, epidemic or endemic maladies." It would also be considerably cheaper than two societies, the dean emphasized. ${ }^{34}$

These were powerful arguments for an administration which contained many holdovers from that of the Empire and which was seeking to promote the reconciliation of pre- and post-revolutionary élites. In a report to the king, the minister of the interior essentially swallowed whole the arguments of the Faculty. ${ }^{35}$ The Society of the Faculty, he asserted, "in fact, now replaces the former Royal Society of Medicine and Royal Academy of Surgery." It could, however, render even greater service if the king agreed to extend its attributes and organize it on a stable footing.

The government's policy during this period was not without a certain incoherence. Soon after the minister's report, the government passed a decree (17 February 1815) abolishing the state educational administration and creating seventeen regional universities under tight regional control. How this would have fit in with the minister's plans for the Paris Medical Faculty is not very clear. In any event, neither measure was implemented. In 1815, Napoleon returned for his final hundred days. When the dust

\footnotetext{
31 See the Ministry's letter of 22 December 1811, in F17 2455.

32 The petition, along with several more detailed reports and speeches, is in F17 3680 .

33 The report is in F17 3680. It is reprinted in Réflexions, op. cit., note 30 above.

34 Ibid., pp. 17-19.

35 Undated report in F17 3680.
} 


\section{G. Weisz}

had settled after his conclusive defeat, the position of the Paris Faculty of Medicine had singularly deteriorated.

Ultra-royalists opposed to reconciliation with the notables of the Empire found themselves immeasurably strengthened; they won a resounding victory in the legislative elections of August 1815 which produced the intransigent Chambre Introuvable. The replacement of the Tallyrand-Fouche ministry by that of Richelieu moved the government somewhat to the right. As a product of the Revolution and Empire, which had, moreover, compromised itself by publicly welcoming the "usurper" after his return from Elba, the faculty was viewed with considerable suspicion by royalists. The traditional opponents of the Faculty, the surgeons of Paris, now had allies in a number of important medical societies: the Academic Society of Paris representing the regent-doctors of the old faculty; the more modern Society of Medicine of Paris; and the Cercle Médical. These could rally behind a new seat of institutional medical power: the physicians and surgeons of the royal court. They could also pursue their aims within a political system that was relatively more open than that of the Empire and which allowed far greater scope to pressure-group politics.

A court medical service had been maintained by Napoleon throughout the years of the Empire. But it was dominated by professors of the Paris Faculty ${ }^{36}$ and, in any case, made no pretence of constituting an autonomous centre of institutional power. On his return to France, Louis XVIII had re-established a wide variety of traditional court positions for his loyal supporters. Among them were a large number of medical titles, often carrying generous stipends. Some of these court physicians resumed use of the traditional name for the king's medical corps, the Faculté du Roi, ${ }^{37}$ which had wielded so much power during the eighteenth century; in this way, they were implicitly claiming for themselves an independent institutional existence and authority rooted in royal patronage and proximity to the king's person. The two most important figures were the king's chief surgeon and chief physician. The man appointed as the king's chief physician at the end of 1815 was none other than Antoine Portal, anatomist at the Collège de France and president of the Cercle Médical. The post of king's chief surgeon was held by Père Elisée (Marie-Vincent Talachon), a secularized member of the Frères de Saint-Jean de Dieu who had emigrated in 1791 and became surgeon to the future Louise XVIII. Elisée is supposed to have been granted authority over medical affairs by the king. His interventions were especially intolerable to professors because he lacked a medical degree and was considered little more than a charlatan. ${ }^{38}$

The campaign to separate surgery from medicine appears to have been launched by a report to the king written by Elisée criticizing the Faculty of Paris in virulent terms and recommending the institutional separation of medicine and surgery. Professors responded with their own pamphlet based largely on their report to the Ministry of the

\footnotetext{
${ }^{36}$ In 1811, for instance, the emperor's first physician was Corvisart and his first surgeon Boyer. The former had retired from the faculty in 1805 but remained an honorary professor; the latter was actively teaching. Of the ten lesser physicians and thirteen lesser surgeons listed (Huard, op. cit., note 28 above, p. 326) three physicians and four surgeons were professors at the Faculty.

37 A. Portal's stationery, for instance, had the words "Service de la Faculte du Roi" printed in the top left-hand corner making it resemble the stationery of the Ministry of the Interior.

${ }^{38} \mathrm{P}$. Hillemand and E. Gilbrin, 'Le père Elisée (1753-1817): premier chirurgien de Louis XVIII', Hist. Sci. méd., 1980, 14: 238.
} 
Interior the year before. In November 1815 , the king appointed a special commission to examine the state of medicine. This unleashed a torrent of pamphlets and articles which did not begin fizzling out until after $1817 . .^{39}$

The main issue, as Paul Delaunay wrote in 1931, was control of medical institutions. ${ }^{40}$ Those without power were demanding either a share in or total domination of leadership of the medical domain. Belief in the unity of medicine and surgery was associated with and had in fact been used to justify the administrative centralization imposed by the Revolution and Empire. It was thus a logical target for critics of the Faculty. The only reason that professors defended the unity of medicine, declared the majority report of the royal commission on medical reform, "is that they wish to retain the administration of the schools, the accumulation of places, their salaries and this absolute empire over all branches of the healing arts which they have exercised for the past 20 years." 41

However, one should not assume that separation of medicine and surgery implied a simple return to local and corporate forms of authority. It was used rather to justify a variety of distinct and irreconcilable programmes and interests. Elisée's position cannot be understood apart from the fact that the king's chief surgeon during the eighteenth century had accumulated virtual dictatorial powers over surgery in France. Elisée's goal thus seems to have been continued centralization but along different lines. Many opponents of the faculty, on the other hand, wished to create corporate bodies giving practitioners greater control over medical institutions. ${ }^{42}$ Questions of authority were complicated by charges that the Faculty was guilty of disloyalty to the monarchy and by claims and counterclaims about who really represented continuity with the traditions of the Royal Society of Medicine and Royal Academy of Surgery. There were also vigorous debates about which system would cost the government less money. But two more substantive issues also helped to shape debates: the nature of both knowledge and practice in medicine and surgery, and the performance of the Paris Faculty in fulfilling its educational, scientific, and professional functions.

First, in the view of some opponents of the faculties, and the traditional opinion in the seventeenth and eighteenth centuries, a common education for both physicians and surgeons was inappropriate because both their tasks and the knowledge on which these tasks were based were separate and distinct. The work of the physician, according to this view, was one of observation, meditation, discernment, and calculation of probabilities in order to grasp the nature of illnesses that were beyond view. It was necessary

\footnotetext{
${ }^{39}$ The polemical literature which appeared during these years is enormous. A few of the more important texts are the majority and minority reports of the reforms commission of 1815-16 in Enquêtes et documents, op. cit., note 9 above, vol. 37, pp. 64-166; Réflexions, op. cit., note 30 above; J.-B. Baumes, Observations sommaires sur l'écrit ayant pour titre, Réflexions sur l'établissement ..., Montpellier, 1816; Opinion de M. Portal sur l'enseignement de la médecine et de la chirurgie ..., Paris, 1820; Chrétien-Lalanne, Considérations sur l'état actuel de la médecine en France: presentées par la Société Académique de Médecine de Paris, Paris, 1818. Léonard in op. cit., note 29 above, pp. 70, 72, cites many other relevant sources.

${ }^{40}$ Delaunay, op. cit., note 29 above, p. 30.

41 In Enquêtes et documents, op. cit., note 9 above, vol. 37, p. 77.

${ }^{42}$ See for instance, Opinion de M. Portal, op. cit., note 39 above, and the majority report in Enquêtes et documents, op. cit., note 9 above, vol. 37 .
} 


\section{G. Weisz}

through the operation of an experienced intelligence, to follow the derangements which intervene in the series and order of interior functions; to go back, through rigorous reasoning, to the causes which become the bases of directions for cure and to choose from among the curative means acknowledged by observations, those which should cure illnesses that can be cured, and alleviate and stop the progress of those which the art cannot conquer. ${ }^{43}$

Surgery, in contrast, was a simpler and more accessible activity based on the application of well-known methods. The senses, experience, dexterity, boldness, and the capacity to ignore the pain of others were paramount. Consequently, the education each required was very different. The physician, having to understand the changes undergone by the body during illness, needed to study a broad range of scientific subjects (chemistry, physics, hygiene) and, above all, needed to "learn at the sickbed the causes, symptoms, progress, the different terminations of illnesses and the curative means indicated by experience." The surgeon required a far more profound knowledge of anatomy, some knowledge of mechanics and, above all, of operating procedures; his studies, therefore, had to be largely practical.

Defenders of the faculty recognized that surgery and medicine were distinct activities; but both, they insisted, were based on a body of medical knowledge that was indivisible. They claimed as well that the vast majority of practitioners ordinarily combined the two activities; surgeons especially could not earn a livelihood by limiting themselves to major operations. Therefore, it was necessary to teach all future practitioners both the medicine and surgery they would require in their practices. ${ }^{44}$

An intermediate position recognized that medicine and surgery had to based on a common foundation but argued that it was dangerous to allow surgeons to practise without a somewhat more elaborate practical training and without passing special examinations. $^{45}$

Second, there was fairly widespread agreement that medical education was not functioning properly. Some professors (elderly, sick, or combining posts in several institutions) did not teach a normal load; ${ }^{46}$ courses were often too short and subject matter not completely covered; examiners were lenient so that diplomas were granted too easily; the faculty had not succeeded in fulfilling its public health and scientific roles. Everyone agreed that too many medical graduates were flooding into the largest cities. But for faculty spokesmen the problem lay with faulty regulations which did not specify the tasks of professors, did not allow for retirement and did not grant the faculty sufficient resources. These could be easily remedied by a wisely-conceived and prudent reform of medical institutions which, for all their weaknesses, had never enjoyed such international recognition, or produced so many fundamental discoveries.

\footnotetext{
43 Baumes, Observations sommaires, op. cit., note 39 above, p. 20. Also see Enquêtes et documents, op. cit., note 9 above, vol. 37, p. 71 .

44 Among the many statements of this position see Réflexions op. cit., note 30 above, pp. 10-14; the report 'Note sur la médecine et la chirurgie' by De Neuville and Laffon de Ladébat, 16 October 1815 in F17 4467; the ministerial report to the king in 1815 (no month given) in F17 3680.

${ }^{45}$ Chrétien-Lalanne, Considérations, op. cit., note 39 above, p. 188.

46 The existence of these abuses is frequently admitted in administrative reports. In 1815 , Georges Cuvier, who was responsible for Faculty affairs on the Commission de l'Instruction Publique governing the education system, complained to the Commission that many professors were not giving their courses; he had, therefore, decided to ask the rectors for a complete list of classes given during the course of the year. Meeting of 5 September 1815, F17 1759.
} 


\section{Constructing the medical élite in France}

Opponents of the faculty viewed matters differently. For them, French medicine had manifestly declined since the golden days of the ancien régime. Abuses were not the result of regulations but of a fundamentally bad system of organization which allowed a small minority to control institutions. Consequently, all competition necessary for improvement was impossible; all manner of patronage and abuse could flourish with impunity. If untrained practitioners were flooding the countryside in numbers that threatened the livelihood of the more competent physicians and surgeons trained before the Revolution, it was because teaching was inadequate, and because it was in the interests of the faculty and of professors to grant as many degrees as possible since fees for diplomas were appropriated by the faculty and were in part used to supplement salaries. The solution, therefore, was to return to an already proven system of corporate control of educational institutions.

As interesting as these debates proved to be, the outcome of events depended primarily on the type of political support which each side was able to mobilize. Opponents of the Paris Faculty had some excellent cards to play: the personal influence which Elisée seems to have exercised over Louis XVIII, widespread suspicion about the loyalty of the faculty to the monarchy, their claim to embody the best traditions of the ancien régime. In 1815, they certainly had the faculty in a panic. But Paul Delaunay was wrong to suggest that only Elisée's sudden death in 1817 prevented their victory. ${ }^{47}$ In fact, the campaign to restructure medical institutions never seems to have gained much support among the political classes, even among the ultra-royalists. The faculty, in contrast, managed to retain the firm backing of administrators in the Ministry of the Interior and the education system. This support undoubtedly reflected the fact that there was no sharp distinction between the administrative personnel of the Empire and that of the Restoration, especialy during these years. Furthermore, Louis XVIII and his government were committed to a course of political moderation incompatible with any serious effort to return to the institutions of the past. Most important, the centralized structures developed during the Empire were supremely useful to a fundamentally despotic government like that of the Restoration. ${ }^{48}$ In the particular case of the Ministry of the Interior, the far-reaching powers of the faculty seem to have been viewed as a necessary means of bringing order and control to the chaotic world of medical practice and public health. Reforms were recognized to be imperative; but they would be in the direction of more rational forms of centralization rather than of decentralization or the concentration of power in the hands of an erratic royal favourite. ${ }^{49}$

\footnotetext{
${ }^{47}$ Delaunay, op. cit., note 29 above, pp. 35-36.

${ }^{48}$ See Spitzer, op. cit., note 29 above, pp. 222-223. Many other institutions initially threatened by the Restoration managed to survive for this reason. On the national bureau of statistics and corps des mines respectively see Bernard-Pierre Lecuyer, 'Les statistiques démographiques et sociales et les statisticiens durant la Restauration', and André Thepot, 'Les ingénieurs des mines dans les sciences et techniques sous la Restauration', both unpublished papers presented to a conference on Science, Medicine and Technology in the French Restoration, which took place at the Maison des Sciences de l'Homme in Paris, 31 August to 2 September 1983.

${ }^{49}$ For a discussion of a parallel process of centralization within the education system see George Weisz, The emergence of modern universities in France, 1863-1914, Princeton, NJ, Princeton University Press, 1983, ch. 1 .
} 
In actual fact, the creation of a commission to reform medicine was vigorously supported by the two administrators chiefly responsible for medicine at the Ministry of the Interior, De Neuville and E. Laffon de Ladébat. ${ }^{50}$ Assured that the Council of Ministers was firmly opposed to the separation of medicine and surgery, they attempted to construct a reform commission dominated by the faculty. However, they appear to have seriously misconstrued the mood at the royal court. On 9 November 1815 , the king did indeed appoint a commission to examine medical institutions, but one dominated by opponents of the faculty. ${ }^{51}$ Equally ominous, the Commission de l'Instruction Publique, the directing body for all public education, was not consulted about the constitution of the commission. ${ }^{52}$

In May 1816, the reform commission produced a report or rather several reports. For it did decide in favour of the separation of medicine and surgery, but only by a vote of eight to six. Their majority report called for separate schools of medicine and surgery controlled by the corps of doctors and surgeons in each city. ${ }^{53}$ The minority, favouring the continued unity of teaching, divided on details and produced three separate minority reports. ${ }^{54}$ That the faculty felt seriously threatened is indicated by the concessions which its dean Leroux and the professor of surgery Dupuytren were willing to make in their minority report. They admitted that regulations governing medical education had isolated the faculties from the corps of physicians and surgeons: "it was forgotten that they [the faculties] were only the agents of the medico-surgical corporations. They were given too much latitude, too much independence, too much power because this power was not grounded on the corporations." 55 To correct this imbalance they suggested that two new institutions be established, one to handle professional discipline, and another responsible for the advancement of medical knowledge. They insisted, moreover, that these be institutionally distinct from each other and from educational institutions. By abandoning the position that the faculty officially dominate an academy of medicine, Leroux and Dupuytren seem to have been guarding against the very real possibility that the faculty would come under the jurisdiction of a new disciplinary or academic institution. "The teaching corps cannot be dependent on its equals," they insisted. It could only be subservient to the minister and the educational administration. ${ }^{56}$

Whatever the actual danger, the government did not act to implement the commission's recommendation. The diversity of opinion within the medical world would certainly have made any attempt at implementation politically hazardous for

\footnotetext{
${ }^{50}$ See their letter dated 13 October 1815 in F17 4467. J.-G. Hyde de Neuville was chief of the third section in the Ministry. As his tenure in that post was brief, it is likely that the memo was actually written by his co-signatory and immediate subordinate, E. Laffon de Ladébat, chief of the Bureau de Secours et des Hôpitaux. The latter would play a key role in the creation of the Academy of Medicine in 1820. Members of a prominent Protestant family, Laffon de Ladébat and his two brothers spent their lives as upper-level civil servants.

${ }^{51}$ Of fourteen medical members only three were Faculty professors.

52 Its protest is in F17 1759, 14 November 1815. Reprinted in Enquêtes et documents, op. cit., note 9 above, vol. 37, pp. 66-67.

${ }_{53}$ In ibid., vol. 37, pp. 64-100. The author was the surgeon Marquais.

${ }_{54}^{54}$ Discussed, ibid., pp. 92-100. One of these, by Leroux and Dupuytren, is reprinted in full, pp. 100-165.

55 Ibid., p. 110. For what follows p. 119.

${ }^{56}$ Ibid., p. 121.
} 


\section{Constructing the medical élite in France}

the government. Action became even less likely when a new minister of the interior, Laine, solicited the opinion of the Commission de l'Instruction Publique officially administering the education system and headed by P.-P. Royer-Collard; the response in January 1817 was an emphatic proposal to disregard the report of the commission majority: "False principles and consequences deduced even more falsely, extreme exaggeration in the reproaches addressed to existing institutions, ignorance of facts, absence of method in the plan presented as in the reasoning, that is what the Commission de l'Instruction Publique has found in this report...."57 Soon afterwards, Elisée died, to be replaced as the king's chief surgeon by, of all people, Dupuytren. The movement to topple the medical élite thus lost its last bit of influence within the royal court. By 1818, the Paris Faculty of Medicine felt secure enough to seek to strengthen its teaching monopoly by petitioning the minister of the interior to put an end to the clinical teaching going on in the Parisian hospitals. ${ }^{58}$

The collapse of the campaign to separate medicine and surgery freed the administration to pursue once again the primary goals set during the last years of the Empire: ending the abuses in medical practice and education while maintaining the existing system of institutions; and improving the government's public health capability while advancing medical science by transforming the Society of the Faculty into an academy of medicine.

\section{THE CREATION OF THE ACADEMY OF MEDICINE}

The question of a public health-research institution, we saw, was near the centre of the debate over the separation of medicine and surgery. The necessity of establishing one or more institutions of this type was recognized by everyone; only the details were in question. Would it extend the powers of the Paris Faculty of Medicine, or would it constitute an autonomous and competing centre of power?

Once the campaign for separation fizzled out, leadership of the opposition to the faculty devolved on Portal, named the king's first physician in late 1815 . He was to abandon the strategy of direct assault pursued by Elisée for more indirect and devious tactics. Even during the debates of 1815-16, he had played a curious role. As a member of the reform commission he had finally voted with the majority favouring the separation of medicine and surgery. But before doing so, he submitted a strange report which argued for a unified system of education for physicians and surgeons. ${ }^{59} \mathrm{He} \mathrm{did,}$ however, implicitly call into question the faculties' dominance over research and public health activities by suggesting that a system of academies or colleges be set up in each department to direct the advancement of medical learning. Although he was willing to forsake titles currently monopolized by public institutions (like "academy"), he insisted (in keeping with his earlier plans for the Cercle Médical) that these societies, made up of all practitioners in an area, be given powers of surveillance and discipline over members. Portal's subsequent actions make it evident that he saw his own Cercle

\footnotetext{
57 Ibid., p. 167.

58 For the response of hospital doctors see their pamphlet Observations des médecins de l'Hôtel Dieu de Paris sur une réclamation faite au nom de l'Ecole de Médecine ..., 20 May 1818; signed by de Montaigu, Asselin, M.A. Petit, Borie, Recamier, Geoffroy.

${ }^{59}$ Opinion de $M$. Portal, op. cit., note 39 above.
} 


\section{G. Weisz}

Médical under the leadership of the king's first physician as the foundation of a Parisian society which would itself assume direction over provincial societies.

By 1818 , it was common knowledge that the government planned to create some kind of Academy of Medicine. ${ }^{60}$ It was also widely known that A. A. Royer-Collard, brother of the politician, and clinical professor at the Faculty, had worked closely with the minister of the interior, Élie Decazes, in preparing a plan for an academy of medical sciences. This plan would subsequently serve as a point of reference for functionaries in the ministry.

The Paris Faculty of Medicine had every reason to welcome a change given its financial constraints. Between 1814 and 1817 , allocations to the faculty declined from 111,000 to 55,000 francs, making it impossible to support the activities of the Society of the Faculty. The minister agreed to the dean's request for a subsidy of 9,000 francs to cover the Society's expenses for two years. He emphasized, however, that "the faculty of medicine should not count on the renewal of this subsidy; and I invite it to search immediately for the means to meet, through its own resources, the expenses of the society it has formed in its midst." ${ }^{, 61}$ Clearly, change in the status of the Society of the Faculty was becoming inevitable.

It was Portal, however, who precipitated matters. The king's first physician managed in 1819 to engineer a reconciliation between the Cercle Médical and the Academic Society which had split apart nearly a decade before. Soon after, he published the essay he had submitted to the reform commission of 1815 , calling for the creation of a system of official medical societies. He then sent this essay to the king along with the request that the reunited Cercle Médical be permitted to assume the title Cercle Royal de Médecine. This petition, we shall see, led to the decision to establish the Academy of Medicine.

Several interpretations have been offered for the government's decision to create the Academy in 1820. According to one account, Louis XVIII was inspired by some features of the proposals submitted by Elisée and Portal in 1815 and merely waited until the passions aroused by the campaign against the faculty had abated before implementing them. ${ }^{62}$ A more sophisticated analysis offered by Huard and ImbaultHuart $^{63}$ recognizes that the proposal to establish an academy had been around for years. The government finally decided to act, according to this view, because the political situation had badly deteriorated as a result of the complot de l'est assassination of the Duc de Berry, and agitation against the electoral law. Its difficulties with the intellectual bourgeoisie prompted the government finally to settle the issue of the Academy. While this interpretation is certainly plausible, there is no evidence to suggest that anyone connected with the creation of the Academy linked it in any way with the larger problem of the intellectual bourgeoisie. I would, therefore, suggest a somewhat different line of argument.

\footnotetext{
${ }^{60}$ There are two unsolicited proposals in the archives of the Ministry in F17 3680 and F17 2738. There is also a letter from Duffour to the Ministry of 3 September 1818 in F17 3679.

${ }^{61}$ The letter from the Ministry dated 4 February 1818 is in F17 6705.

$62 \mathrm{P}$. Hillemand and E. Gilbrin, 'Le Père Elisée, premier chirurgien de Louis XVIII, et la création de l'Académie de Médecine', Bulletin de l'Académie Nationale de Médecine, 1981, 165: 23-26.

${ }^{63}$ P. Huard and M.-J. Imbault-Huart, 'La première séance de l'Académie Royale de Médecine', Bulletin de l'Académie Nationale de Médecine, 1971, 155: 414-423.
} 


\section{Constructing the medical élite in France}

The government in 1820 was interested in establishing one or several academies for exactly the same reasons that had prompted its initiatives in 1814. Its growing involvement in health care necessitated a centralized institution that could develop and transmit the specialized knowledge required for effective action. Furthermore, creating an Academy with much fanfare and publicity could provide legitimation for a government which badly needed legitimation by underlining the monarchy's humanitarian commitment to the welfare of its people and to the best features of the ancien régime. There existed a virtual consensus about the need for some such sort of institution. But, as we saw, its advocates were divided into two camps. The government might have imposed a compromise before 1820 except for the fact that the proposal to establish an Academy independent of the Faculty was swallowed up in the far more radical campaign to separate surgery from medicine and dismantle the existing institutional machinery. This was unthinkable even for the most conservative of restoration ministries which those of 1815 to 1819 most definitely were not. After 1817, however, the proposal for an autonomous academy became gradually disentangled from the radical assault on the faculties. Presented in the most moderate fashion by Portal, a man close to the royal court and with impeccable scientific credentials, the plan attracted support in royalist political circles becoming increasingly hostile to the education system. The personnel of the ministry of the interior and the Paris Faculty of Medicine were obviously opposed to this sort of academy. But the former, confident of their ability to determine the outcome of events and desperate to put the public health-research tasks of the faculty on a sounder financial footing, pressed ahead, somewhat recklessly, one sees with the benefit of hindsight, for a resolution of the stalemate. This allowed the government to impose a compromise.

The ministry's insistence on forging ahead at all costs was a virtual repeat of its insistence on convening a reform commission in 1815 , despite the dangers posed by opponents of the faculty. (Indeed, the same person, Laffon de Ladébat, played a major role in defining policy in both cases.) In 1820 , however, the ministry had an added motive for precipitating events. Since 1817 , it had been attempting to decide how best to react to the epidemic of yellow fever raging across the border in Spain. The Paris Faculty of Medicine had been consulted in 1817, a commission was sent to Cadiz in 1819 , and in November 1820, about one month before the appearance of the ordinance establishing the Academy, the government appointed a Central Sanitary Commission to elaborate appropriate sanitary legislation. The result was the passage of the Sanitation Law of 1822 and the creation several months later of a Superior Council of Health to oversee the apparatus of quarantine, disinfection, and cordons sanitaires. ${ }^{64}$ Consequently, the creation of the Academy must also be seen in the context of a wide-ranging effort to cope with epidemics.

In March 1820 - soon after Decazes' liberal ministry fell, to be replaced by the more conservative Richelieu government-Portal petitioned the king asking that the word

\footnotetext{
${ }^{64}$ On these matters see Ann E.F. La Berge, 'Public health in France and the French public health movement 1815-48', PhD thesis, University of Tennessee, 1974, especially pp. 116-117; and George D. Sussman, 'From yellow fever to cholera: a study of French government policy, medical professionalism and popular movements in the epidemic crises of the Restoration and July Monarchy', PhD thesis, Yale University, 1971.
} 


\section{G. Weisz}

"Royal" be added to the name Cercle Médical. ${ }^{65}$ The king ordered Portal to address himself to the minister of the interior, indicating that he himself was favourably disposed to the request; or so it seemed to functionaries of the ministry of the interior who learned of the petition immediately. Within two days, the two officials responsible for medical institutions, Baron Capelle and Laffon de Ladébat, prepared a report to the minister ${ }^{66}$ firmly opposing Portal's request on the grounds that the Society of the Faculty was already the government's chief advisory body for all health matters. Since 1815 , moreover, the ministry had been developing a plan to establish a royal society. Allowing the Cercle Médical to assume the title "Royal" might, they argued, nip this initiative in the bud.

When Portal finally got around to sending his proposal to the Ministry of the Interior ${ }^{67}$ he was conciliatory. His letter spoke of the need for an academic society with powers of professional discipline and surveillance in addition to its responsibility over public health and medical science. He suggested that a special commission be appointed to discuss the possibility of the most appropriate form for such a society. He did insist, however, that the commission be broadly representative of the profession, bringing together "the sometimes opposed interests and pretensions of the various medical functions." He proposed a commission of eight members on which professors were a minority.

Despite fears regarding Portal's intentions and influence at court, ${ }^{68}$ Baron Capelle chose to utilize Portal's request in order to further his own plan for an academy of medicine. On 27 April, he and Laffon de Ladébat submitted a report to the minister ${ }^{69}$ advising that the Cercle Médical should not be granted use of the term "royal". Instead, they insisted on the need to establish a new institution. A sly effort was made to placate Portal by suggesting that the presidency of the body be conferred on the king's first physician. In order to implement their suggestion, the authors proposed the nomination of a commission to discuss whether to satisfy Portal's request or establish a completely new academic society. The commission, it was claimed, was. representative enough "to provide for and reconcile everyone in the Faculte du Roi, the Paris Faculty of Medicine, civil medicine and military medicine." However, of the nine members suggested and soon after appointed (under the chairmanship of Georges Cuvier), only Portal and the councillor of state, de Gérando, were not members of the Society of the Paris Faculty of Medicine. ${ }^{70}$

This flurry of activity was only the first round in an intense process of political manoeuvering dominated, according to the Revue médicale, by intrigues, agitation,

\footnotetext{
${ }^{65}$ Letter of 15 March 1820 in F17 3680.

${ }^{66}$ Report of 17 March 1820 in F17 3680. Laffon de Ladébat was still chief of the Bureau de Secours. His immediate superior was Baron Guillaume Capelle, secretary-general of the Ministry of the Interior. Capelle had been ennobled by Napoleon after an administrative career under the Empire. He was in serious trouble with the emperor for having surrendered Geneva in 1813 when he adhered to the Bourbons in 1814. He became a councillor of state in 1816.

${ }^{67}$ Letter of 5 April in F17 3679.

${ }^{68}$ See especially a remarkable letter from A.-A. Royer-Collard to Cuvier found in the dossier of A. Portal at the Academy of Sciences.

69 In F17 3680.

70 The members were Cuvier (president), de Gérando, Portal, Alibert, Le Roux, Chaussier, Richerand, Royer-Collard, and Desgenettes.
} 


\section{Constructing the medical élite in France}

and "egoism beneath the mask of the public weal". ${ }^{71}$ Portal sought without success to get a more representative commission. ${ }^{72}$ As a result of his failure, the commission's report, completed in July $1820,{ }^{73}$ faithfully reflected the view of the Faculty. Claiming to have achieved unanimity on all major points, the commission refused to accord the title "royal" to either the Cercle Médical or the Society of the Faculty on the grounds that a successful academic society needed to be "a creation of the government". It thus proposed the founding of a Royal Academy of Medical Sciences composed of distinct sections of medicine, surgery, and pharmacy. The commission made no provision for a permanent president, calling instead for an annual presidency rotating among the three sections. This would leave Portal with no base from which to assert leadership. It also argued for a small academy with membership of 180 (not including correspondents and adjuncts) on the grounds that the Academy should not be a representative college, but like the academies of the eighteenth century, a working corps. Finally, it stipulated that however nominations were to be effected, all faculty professors and all associates and adjuncts of the Society of the Faculty were to be admitted as members.

Capelle transmitted the commission's report to the minister with his own warm endorsement. ${ }^{74} \mathrm{He}$ also suggested a procedure for nominations that he thought would protect the government against charges of favouritism. The king would name only a portion of the members, who would proceed to elect their remaining numbers. He was, however, very specific about those to be named: twenty-four professors of the Paris Faculty, twenty members of the Society of the Faculty, six professors of the Paris School of Pharmacy, two professors of the Collège de France (including Portal), and four secretaries of authorized medical societies. Aside from placing the Academy firmly in the hands of the Faculty, Capelle's list named Portal in his capacity as professor (at the Collège de France) rather than as the king's first physician, emphasizing that he was merely one member among equals.

Portal reacted with great moderation. In a letter to the minister, Siméon, ${ }^{75}$ he made only two specific suggestions: that several Academy-wide committees were needed to bring together members from the different sections and, more significantly, that the number of associates and adjuncts be greatly increased. In defence of this second proposal, he argued that greater public interest in the Academy would thus be stimulated and, above, all, that the institution needed to be representative of Parisian practitioners "in order to extract from the academic societies of Paris a large segment of their supporters; this would be the best method of extinguishing them without directly abolishing them." Manifestly, Portal was still pursuing his dream of a single official society for the Paris region capable eventually of appropriating powers of professional discipline and surveillance.

Portal's tone of moderation may have reflected self-confidence. Indeed, the political situation was evolving in his favour. After the assassination of the Duc de Berry, the influence of the ultra-royalists grew apace, culminating in the formation of the Villèle ministry in December 1821. Hostility to the Faculty of Medicine was increasing as well,

\footnotetext{
71 'Lettres médicales sur Paris', Revue médicale, 1821, 5: 328-330.

${ }^{72}$ Letter of 8 May 1820 in F17 3680.

${ }^{73}$ In F17 3680.

${ }^{74}$ In F17 3680.

7526 July 1820 in F17 3680 .
} 


\section{G. Weisz}

partly as a result of the general tendency to abandon the policy of reconciliation with the notables of the Empire and partly due to widespread student disturbances directed against the electoral law. Matters would reach a head in 1822 when the government closed down the Paris Faculty of Medicine, re-opening it several months later minus eleven professors who were dismissed from their posts and replaced. ${ }^{76}$ At the end of 1820 , things had not yet deteriorated so dramatically. But especially after the victory of the ultra-royalists in the legislative elections held in November, a gesture repudiating the faculty of medicine without really tipping the existing balance of institutional power must have seemed attractive to many.

On 19 December 1820, the Faculty acknowledged Portal's growing influence by recommending, subject to ministerial approval, that Portal be named as an associate of the Society of the Faculty. ${ }^{77}$ The next day a royal ordinance established the Royal Academy of Medicine. Seven days later, the first members were appointed by the king. ${ }^{78}$

The statement of introduction to the ordinance of 1820 essentially repeated the rationales elaborated in all of the earlier recommendations for the creation of an academy. The long-range goal was "to perfect the teaching of the healing art and to end the abuses introduced into the exercise of its different branches" by establishing under royal protection an institution charged with advancing medical science. The more immediate task was to respond to questions from the government "concerning everything relevant to public health," principally epidemics, epizootics, legal medicine, the propagation of smallpox vaccination, and the examination and analysis of new remedies and mineral waters. ${ }^{79}$ It was also to concern itself with all research that might contribute to the progress of medicine.

The ordinance called for an academy made up of three sections, medicine, surgery, and pharmacy, of unequal size ${ }^{80}$ These were to meet regularly in separate sessions and more infrequently in combined session. Members were divided into five hierarchical categories, with decision-making powers concentrated in the ranks of the titulaires.

The ordinance differed in several respects from the proposal submitted by the Cuvier commission and Baron Capelle. The new institution was to be called Academy of "Medicine" rather than "Medical Sciences", more directly emphasizing the unification of the medical professions within it. The king's first physician was designated permanent honorary president. Most important, Portal had his way with respect to size: the Academy was to be composed of 285 members (in addition to an indeterminate number of corresponding and adjunct members) rather than the 180 recommended by Cuvier and Capelle (Table 1). The full significance of this figure becomes more evident if we note that there were only 571 physicians and surgeons and 197 pharmacists officially registered in the Paris region in $1820 .^{81}$ The huge

\footnotetext{
${ }^{76}$ The most complete discussion of these events is Charles Odic, 'Les évènements du 18 novembre 1822', thèse en médecine, Université de Paris, 1921. Also see P. Menetrier, 'Le centenaire de la suppression de la Faculté de Médecine de Paris’, Bull. Soc. française Hist. Méd., 1922, 16: 441-445.

77 F 172544.

${ }^{78}$ The two ordinances are reprinted in Mémoires de l' Académie Royale de Médecine, 1828, 1: 1-15.

79 Ibid., pp. 1-2.

${ }^{80}$ Membership in the three sections was to be on a ratio of $3: 2: 1$.

81 These figures were arrived at by counting the practitioners listed in the Almanach Royal of that year.
} 


\section{Constructing the medical élite in France}

\section{TABLE 1. MEMBERSHIP OF THE ACADEMY OF MEDICINE}

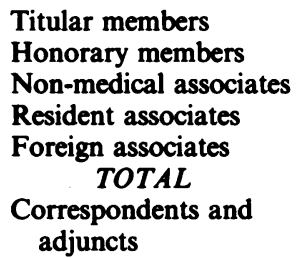

Titular members

Honorary members

Non-medical associates

TOTAL

adjuncts

$\begin{array}{cc}\text { Commission proposal } & \text { Ordinance } \\ 80 & 85 \\ 20 & 60 \\ 20 & 30 \\ 40 & 80 \\ 20 & 30 \\ 180 & 285 \\ 70 & \text { Not } \\ & \text { determined }\end{array}$

membership was due essentially to a decision to swell the ranks of the honorary members and associates. While this would bring a swarm of Parisian practitioners into the Academy, its practical effects were to be somewhat limited by the fact that neither category was supposed to have decision-making powers over internal affairs.

The ordinance of 27 December, nominating the first cohort of members (which was to elect the rest of the membership) also differed significantly from Capelle's proposal which would have given the faculty overwhelming predominance (Table 2). Contemporaries believed that the Faculty named half the members while Portal named the other half. This seems a reasonable supposition given the results. Faculty professors obtained twenty-one of sixty-nine appointments, with another nine chosen from among professors in the school of pharmacy. No less than ten other appointees were associated with the royal medical corps.

It is worth noting that at this stage political considerations do not seem to have played a determinate role in the nominations. If a number of well-known monarchists like Esquirol, Hallé, and Alibert were appointed, so were figures identified with the Empire and even liberal opponents of the monarchy like Broussais. The government seems to have accepted choices made by the Faculty and by Portal according to other than political criteria.

TABLE 2.TITULAR AND HONORARY MEMBERS IN THE ACADEMY OF MEDICINE: INITIAL COHORT

\begin{tabular}{|c|c|c|c|c|}
\hline & Commission & \multicolumn{3}{|c|}{ Ordinance } \\
\hline & & Total & & Honorary \\
\hline Professors, medicine & 24 & 21 & 16 & 5 \\
\hline Professors, pharmacy & 6 & 9 & 6 & 3 \\
\hline Society of the Faculty & 20 & a & a & $\mathbf{a}$ \\
\hline Collège de France & 2 & a & a & a \\
\hline Medical societies & 4 & a & a & $\mathbf{a}$ \\
\hline Faculté du Roi & b & 10 & 7 & 3 \\
\hline Doctors, civil hospitals & b & 9 & 5 & 4 \\
\hline Doctors, military hospitals & b & 6 & 4 & 2 \\
\hline Other & b & 14 & 6 & 8 \\
\hline TOTAL & 56 & 69 & 44 & 25 \\
\hline
\end{tabular}

(a) Members were not identified by these institutional affiliations. We do know, however, that some did fit into these categories in addition to their primary identification.

(b) No special mention is made of these categories. 


\section{G. Weisz}

While clearly a slap in the face for the Faculty, this initial selection allowed it to retain significant influence. As the Revue médical recognized, only the forty-four men named as titular members were to elect the remaining members. Professors in the Faculty of Medicine and School of Pharmacy constituted exactly one-half of these forty-four titulaires. Another six titular members, moreover, were associates or adjuncts of the Society of the Faculty. Subsequent nominations, however, greatly diluted the Faculty's influence. Honorary members (and forty more were elected in 1823) soon achieved parity with the titulaires and, in 1835, resident associate status was eliminated allowing the seventy-three current associates to become full members. A membership of nearly 200 made it difficult for Faculty professors to assert leadership, especially in view of the fact that the Academy's two chief officers, the permanent president and secretary (Portal and Etienne Pariset, respectively) were not members of the Faculty.

This situation was temporary, since the ministry soon decided that the Academy's operational problems were due, at least in part, to excessive size; consequently, it replaced very few of the members who died. In 1829, the government formalized this practice in a major reorganization of the Academy. Among other things, it was decided to fill only one in every three vacancies until membership fell to 100,82 a figure reached only during the Second Empire. Over the long run, nonetheless, the gradual shrinking of the Academy together with the growth of the Paris Faculty of Medicine allowed the latter slowly to regain control of the former. By 1914, forty-one per cent of the academicians taught at the Faculty with another eight per cent at the School of Pharmacy. ${ }^{83}$ Four of the five men who served as permanent secretary of the Academy from 1873 to 1944 were professors at the Faculty of Medicine. ${ }^{84}$ By the Third Republic, therefore, the Ministry of the Interior had apparently achieved its initial goal; the Academy of Medicine was, in effect, an extension of the Paris Faculty of Medicine.

\section{CONCLUSION}

What is perhaps most striking about the institutional history of French medicine from the eighteenth century on is the role of the state in creating a medical élite, and indeed, establishing a medical profession in the modern mode. Sociologies of the profession based on the histories of England and United States (when history is taken into account) have neglected the state's role and are thus largely irrelevant to the history of the professions throughout much of continental Europe. ${ }^{85}$ They have also

\footnotetext{
${ }^{82}$ Even more important was the decision to abolish the three sections of medicine, surgery, and pharmacy and to create eleven much smaller and far less autonomous sections based on disciplinary division.

${ }^{83}$ More generally, the Academy was taken over by a medical public service élite. In 1832, 81 out of 194 academicians were listed in the Almanach Officiel without any title other than practitioner of medicine, surgery, etc. In 1913, only three out of 108 members were described only as practitioners.

${ }^{84}$ These were J. Béclard (1873-87), S. Jaccound (1900-13), G. Debove (1913-20), and C. Achard (1920-44). The office of permanent president was eliminated after Portal's death in 1832, leaving the permanent secretary as the dominant figure in the Academy.

${ }^{85}$ A similar conclusion has been reached by Gerald Geison in his introduction to G. L. Geison (editor), Professions and the French state, 1700-1900 Philadelphia, University of Pennsylvania Press, 1984. The problem, I would emphasize, is primarily at the theoretical level. Detailed historical studies, even by sociologists, cannot fail to recognize the importance of politics and professional stratification. But their discussions do not really fit in with the theoretical orientations they borrow from writers like Freidson,
} 
tended to ignore internal stratification and conflict, which has not been a by-product of the professionalization process, but rather, one of its central features. To be sure, some complicity among all parties in such conflicts has often existed. None of the actors in our story, for instance, questioned the politico-administrative role of a medical élite. Still, the outcome of disagreements has on occasion profoundly shaped the evolution of French medicine. The question of separating or unifying medicine and surgery involved fundamental definitions of the medical domain that were hardly trivial. Creating an academy of medicine ultimately consolidated the existence of a national élite far more powerful and homogeneous than those found in many other nations.

The fact that the Restoration chose to perfect, extend and make more tractable a system of medical authority that was in many respects still unenforceable, also inaugurated a style of internecine professional conflict that continues to mark French medicine. For nearly 200 years, almost any issue of education, administration, or regulation has had the potential of flaring up into a battle for medical dominance. The current struggle to transform hospitals by creating American-style departments with elected heads is only its most recent manifestation. Now, as in the past, rival coteries within the medical domain seek allies within the political classes. Now, as in the past, the cards are firmly stacked in favour of those who seek to maintain rather than transform existing power relations.

Johnson, and Larson. My own response to theoretical gaps of this nature has been to make the medical "domain" (see note 2) rather than the "profession" the basic unit of analysis. For another response to the inadequacy of "professionalization" theory see Jan Goldstein, "Foucault among the sociologists: the "disciplines" and the history of professions', History and Theory, 1984, 2: 170-192. 